\title{
ENERGY EXPENDITURE IN VOCALIZATIONS OF PIGS UNDER STRESS
}

\section{ALEXANDRA F. DA S. CORDEIRO ${ }^{1}$, IRENILZA A. NAAS ${ }^{2}$, BRENDA B. MEDEIROS ${ }^{3}$, ANA PAULA DE A. MAIA ${ }^{4}$, ERICA M. PEREIRA ${ }^{5}$}

\begin{abstract}
Modern swine production faces many challenges nowadays, among which are productivity growth, meat quality improvement, decrease of environmental damage and reduction of cost production. Pigs spend energy to vocalizing, especially when they undergo stress. The waste of energy can increase the cost of production and lead to greater environmental damage. The goal of this study was to estimate the energy spent by pigs under the stress of castration and its effect on the animals' weight gain. Two groups of ten animals each were castrated, being one group with local anesthetic and the other without anesthetic. The piglets' vocalizations were recorded during different stages of the neutering process and then estimated of the amount of energy emitted during each vocalization. Afterwards, this energy was associated with the animals' weight gain. There was no difference in the total energy spent in both groups, since the energy used during the application of anesthetic was similar to the energy spent during the castration of the animals without anesthetic. There was also no correlation between energy spent and the animals' weight gain. It was possible to estimate the amount of energy emitted through vocalization. This energy spent by piglets in pain was greater than in other handling situations (contention, weighting and realease).
\end{abstract}

KEYWORDS: animal well-being, signal analysis, swine production.

\section{GASTOS DE ENERGIA NA VOCALIZAÇÃO DE SUÍNOS SOB ESTRESSE}

RESUMO: A suinocultura moderna enfrenta muitos desafios, dentre os quais o crescimento da produtividade, a melhoria da qualidade de carne, a redução de danos ambientais e a redução de custo de produção. Suínos gastam energia na vocalização, especialmente quando submetidos a determinado estresse. O desperdício de energia pode aumentar o custo de produção e conduzir a um maior dano ambiental. O objetivo deste estudo foi estimar a energia gasta pelos leitões sob o estresse da castração e seu efeito sobre o ganho de peso dos animais. Dois grupos de dez animais cada foram castrados, sendo um grupo com anestesia local e outro sem anestesia. As vocalizações dos leitões foram gravadas durante as diferentes fases do processo de castração, sendo objeto de uma estimativa da quantidade de energia emitida durante cada vocalização. Posteriormente, esta energia foi associada com o ganho de peso dos animais. Não houve diferença no gasto total da energia em ambos os grupos, uma vez que a energia utilizada durante a aplicação da anestesia foi semelhante à energia gasta durante a castração dos animais sem anestesia. Também não houve correlação entre a energia gasta e o ganho de peso dos animais. Foi possível estimar a quantidade de energia emitida através de vocalização. Esta energia gasta por leitões com dor foi maior do que em outras situações de manejo (contenção, pesagem e soltura).

PALAVRAS-CHAVE: bem-estar animal, análise de sinais, produção de suínos.

\footnotetext{
${ }^{1}$ Zootecnista, Doutora em Engenharia Agrícola, Faculdade de Engenharia Agrícola, UNICAMP.

${ }^{2}$ Engenheira Civil, Professor Colaborador, Faculdade de Engenharia Agrícola, UNICAMP .

${ }^{3}$ Zootecnista, Doutora em Engenharia Agrícola, Faculdade de Engenharia Agrícola, UNICAMP.

${ }^{4}$ Zootecnista, Doutoranda em Engenharia Agrícola, Faculdade de Engenharia Agrícola, UNICAMP.

${ }^{5}$ Engenheira de Telecomunicações, Doutora em Engenharia Agrícola, Faculdade de Engenharia Agrícola, UNICAMP.

Recebido pelo Conselho Editorial em: 19-7-2012

Aprovado pelo Conselho Editorial em: 16-3-2013
} 


\section{INTRODUCTION}

The increase in the world demand for food is a major concern. Population growth and increase in people's income are elements that lead to the increase in consumption of animal protein products. Pork is the most consumed meat in the world, and its production requires special attention in order to obtain the lowest production cost, the lowest environmental damage and the best quality product. The raise of energy expenditure by animals increases their food intake, resulting in higher production costs and greater environmental implications, especially in terms of the animals' nutrition and waste. The animals spend energy vocalizing, mainly when exposed to stressful situations (CORDEIRO et al., 2009).

Male castration in livestock production is usually done without anesthetic or analgesic, and includes various painful procedures, such as scrotal incision, testicular extraction and removal of the spermatic cord (TAYLOR \& WEARY, 2000). Pigs are castrated to avoid the occurrence of the distinctive swine odor and flavor in the meat, diminishing its quality and, subsequently, devaluing it. The castration of piglets is a common technique used in animal production handling. Animals destined to slaughter can be castrated during any age; however, since there are benefits in castrating the animals during the first weeks of their lives, this procedure often takes place when the piglets are approximately seven days old. The older the animal, the higher the risks of surgical complications, such as hemorrhage, difficulties in the scar healing process, infections and other conditions that may lead to the animals' death. Nowadays, some studies are focusing on an immunological castration technique in order to ease the animals' pain, substituting the painful conventional neutering procedure (PAULY et al., 2009; MORAES et al., 2010).

Animal welfare is the object of studies by various authors (COSTA, 2008; SILVA et al., 2007; COSTA et al., 2007). In swine production, vocalization is an important tool used to identify animal welfare (MOURA et al., 2008), to determine pathologies (RISI, 2010) and to assess the thermal comfort thresholds (TOLON et al., 2010).

Energy expenditure in vocalization is a matter poorly explored, but it requires special attention, since it aides animal handling by identifying situations that stimulate the animals to emit high energy vocalizations, leading to diminishing production costs.

The goal of this study was to estimate the energy spent by pigs in vocalization during the stress of castration, and its effect on the animals' weight gain.

\section{MATERIALS AND METHODS}

The experiment was set in a swine commercial farm located in the city of Holambra, São Paulo State, Brazil, latitude $22^{\circ} 37^{\prime} 59^{\prime \prime} \mathrm{S}$ and longitude $47^{\circ} 03^{\prime} 20^{\prime \prime} \mathrm{W}$. The data acquisition process of recording the vocalization sounds took place during the farrowing stage of the piglets, throughout the castration procedures. Twenty piglets with ages between three and four days were divided into two groups of 10 animals each. The piglets in the first group were castrated without anesthetic, whereas the second group was castrated with local anesthetic. The experiment protocol had the approval of UNICAMP' Ethics Committee (2224-1/2011).

In order to verify a possible correlation between weight gain and energy spent in vocalization during castration, the piglets were weighed before and after the neutering procedure, using a Toledo $^{\circledR}$ digital balance with $15 \mathrm{~kg}$ of maximum weight and $0.005 \mathrm{~kg}$ of precision. After the procedure, the animals were weighed along with the removed testicles, which were placed in a previously weighed container. The utilized castration method was the scrotal castration, in which a small longitudinal incision was made over each testicle, through which the spermatic cord was tractioned until it ruptured and the testicles were removed. Before the removal, all animals were put on their back sand underwent antisepsis of the scrotal region with topical Iodine, after which was applied the anesthetic Lidocaine (20\%) on the 10 piglets of the second group, ten minutes before the incision. After the removal of the testicles, topical Iodine was used for cleansing. 
The sound signals emitted by each animal during the castration procedure were gathered, by using a Yoga ${ }^{\circledR}$ unidirectional microphone positioned at approximately $20 \mathrm{~cm}$ from the animals. This microphone was connected to a Marantz ${ }^{\circledR}$ PMD 660 digital recorder on which the signals were digitalized into a $44.100 \mathrm{~Hz}$ frequency (Nääs, et al. 2008). The sound signals emitted by each animal were gathered in different stress situations (Table 1).

TABLE 1. Description of the stress situations the animals underwent throughout the castration procedure.

\begin{tabular}{ll}
\hline \multicolumn{1}{c}{ Condition } & \multicolumn{1}{c}{ Description } \\
\hline A (first weighting) & Weighting the piglet prior to castration \\
B (second weighting) & Weighting the piglet after castration \\
C (anesthetic) & Applying the anesthetic with the meddle in the testicles \\
D (handling) & Holding tightly the piglet by their limbs \\
E (castration) & Castration surgery procedure \\
F (contention) & Holding the piglet in the proper box \\
G (release) & Returning the animals to their original rooms \\
\hline
\end{tabular}

At the end of the farrowing and nursery phases, the animals were weighed individually. In order to determine the energy emitted during vocalization, an algorithm developed in Matlab ${ }^{\circledR}$ environment was used, as described by CORDEIRO et al. (2009). The algorithm initially carries the audio signals captured and then does the calculation of the Hilbert transform to obtain the envelope signal and the energy emitted. The total energy of the signal also considered the duration of the signal.

Statistical data analysis was performed by ANOVA ( $p>0,05)$. Furthermore, the Pearson test was used to explore the correlation between the energy emitted in vocalization and the difference in weights shown during the weighing procedure. In addition to that, the Pearson test was utilized to measure the correlation between the energy spent and the final weight of the piglets in farrowing (from the birth until 21 days old), and nursery (from 21 to 60 days old). All analyses were done using the software Minitab ${ }^{\circledR}$.

\section{RESULTS AND DISCUSSION}

No difference $(\mathrm{p}>0.05)$ was found between the energy emitted in the total vocalization of the animals castrated without anesthetic $(3.403,87 \mathrm{~kJ})$ and the animals with local anesthetic $(6.079,23$ $\mathrm{kJ})$. However, the energy emitted during vocalization by pigs castrated without local anesthesia was nearly twice as much as the energy emitted by those castrated without anesthesia. This can be explained by the total time of manipulation of the animal during the procedure, which is longer when anesthesia is applied. The found values were not significant probably due to the high value of variation coefficient for the group castrated without anesthesia (156.67) and the vale for those castrated using anesthesia (167.57). NÄÄS et al. (2008) also found individual differences in vocalization of pigs submitted to a similar type of stress. In the results of the energy emitted during each phase of the castration procedure it is observed that, for the group castrated with anesthetic, the greatest energy expenditure occurred during the application of the anesthetics; as for the group castrated without anesthetic, the greatest expenditure happened during the castration surgery. Aside from that, there was no difference in the energy emitted in vocalization during the other phases of the procedure, explaining why the total energy emitted in vocalization was not different for both groups. The application of anesthetics (for the second group of piglets) and the castration surgery (for the first group) represented pain for the piglets, being similar to each other and different from other situations of the procedure.

MARX et al. (2003) also observed that the pigs emit more energy when they scream (due to pain exposure) than when they grunt. The great variation of data during the application of the 
anesthetics (for the second group) and during the castration surgery (for the first group) reflects the difference in the animals' individual responses to pain. The results suggest that local anesthesia causes the same intensity of pain than the castration itself, being, therefore, an additional stress. Alternatives, such as immune-castration or the rearing of intact males are becoming more prevalent, and the needs for castration will tend to diminish in livestock production (RAULT et al., 2011).

There was no correlation between the energy emitted in vocalization and the final weight during farrowing and nursery phases (Table 2). According to the results, energy emission in the animals' vocalization had no impact on its weight gain. Other elements that were not controlled in this experiment could have influenced the results. According to KUMMER et al. (2009), genetic, nutritional, sanitary, and environmental factors, along with workers' handling, might influence performance of the piglets in the nursery phase.

TABLE 2. Correlation between energy emitted in vocalization during castration and the final weight of the piglets during farrowing and nursery.

\begin{tabular}{lcc}
\hline Piglet's weight & Pearson's correlation & p-value \\
\hline Farrowing & 0.023 & 0.924 \\
Nursery & -0.191 & 0.448 \\
\hline
\end{tabular}

There was a difference in weight gain at the end of farrowing and nursery phases (Table 3).The animals with lower weight gain during farrowing tended to gain more weight during nursery phase (Figure 1). These results differ from those found in the literature (SMITH et al., 2007), since animals with higher weight during nursery tend to present higher weight at the end of first phase of growth. DALLANORA, D. et al. (2010) suggest that the piglet quality in each phase interferes in the performance in subsequent period. However, according to HÖTZEL \& MACHADO FILHO (2004) social modifications, as well as rearing and nutrition changes may lead to decrease in growth during the period of weaning.

TABLE 3. Average weight gain (WG, $\mathrm{kg}$ ) of the animals during farrowing and nursery phases, divided by the groups with and without anesthesic.

\begin{tabular}{|c|c|c|}
\hline \multirow[b]{2}{*}{ Weight gain (WG) } & \multicolumn{2}{|c|}{ Anesthesic } \\
\hline & With & Without \\
\hline Farrowing & $2.2525 b$ & $2.9475 a$ \\
\hline Nursery & $13.775 \mathrm{a}$ & $12.210 \mathrm{~b}$ \\
\hline
\end{tabular}

Obs. WG during castration reflects the weight lost by the animals during the procedure.

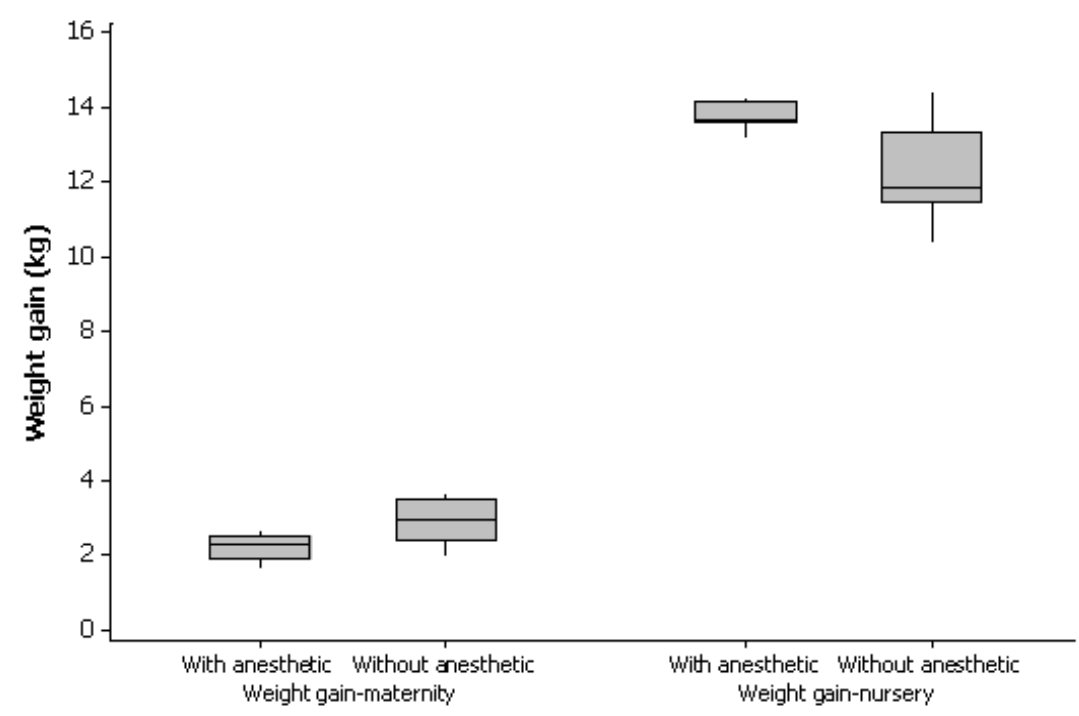

FIGURE 1. Weight gain profile of pigs castrated with anesthesic and without anesthesic. 


\section{CONCLUSIONS}

It was possible to estimate energy expenditure during swine vocalization. The energy spent in vocalization by piglets in situations of pain is greater than in other situations. The discussion about the use of anesthesic before castration must be thoroughly studied in order to not make neutering a procedure even more painful to the animal.

\section{REFERENCES}

CORDEIRO, A. F. S.; PEREIRA, E. M.; NÄÄS. I. A.; SILVA, W. T.; MOURA, D. J. Medida de Vocalização de Suínos (Sus scrofa) como um Indicador de Gasto Energético. Brazilian Journal of Biosystems Engineering, Campinas, p.2, p. 2, 2009.

COSTA, A.N. Produção e bem-estar animal aspectos técnicos e éticos da produção intensiva de suínos. Ciência Veterinária nos Trópicos, Recife, v. 11, n. 1, p. 43-48, 2008.

COSTA, O.A.D.; LUDKE, J.V.; COSTA, M.J.R.P.; FAUCITANO, L.; PELOSO, J.V.; ROZA, D.D. Modelo de carroceria e seu impacto sobre o bem-estar e a qualidade da carne dos suínos. Ciência Rural, Santa Maria, v.37, n.5, p. 1418-1422, 2007.

DALLANORA, D.; MACHADO, G.S.; BIONDO, N. Impacto da qualidade dos leitões desmamados sobre o desempenho posterior nas creches terminações. Acta Scientiae Veterinariae, Porto Alegre, v. 37, p. 171-180, 2010.

HÖTZEL, M.J.; MACHADO FILHO, L.C.P.; Comportamento e bem-estar dos leitões em relação ao desmame. Porkworld, Paulina, São Paulo, p. 34 - 38, 01 jul. 2004. Disponível em: http://www.freewebs.com/hotzel/PorWorld2004.pdf. Acesso em: 28 fev. 2013.

KUMMER, R.; GONÇALVES, M.A.D.; LIPPKE, R.T.; MARQUES, B.M.F.; MORES, T.J. Fatores que influenciam o desempenho dos leitões na fase de creche. Acta Scientiae Veterinariae, Porto Alegre, v. 37, n. 1, p. 195- 209, 2009.

MARX, G.; HORN, T.; THIELEBEIN, J.; KNUBEL, B., BORELL, E. Analysis of pain-related vocalization in young pigs. Journal of Sound and Vibration, Amsterdam, v. 266, n. 3, p. 687-698, 2003.

MORAES, E.;KIEFER, C.; IANDARA SCHETTERT SILVA, I. S.Ractopamina em dietas para suínos machos imunocastrados, castrados e fêmeas. Ciência Rural, Santa Maria, v.40, n.2, p.409$414,2010$.

MOURA, D. J.; SILVA, W.T.; NÄÄS, I.A.; TOLON, Y.B.; LIMA, K.A.O.; VALE, M.M.Real timecomputer stress monitoring of piglets using vocalization analysis. Computers and Electronics in Agriculture, Amsterdam, v.64, n.1, p.11-18, 2008.

NÄÄS, I.A.; CAMPOS, L.S.L.; BARACHO, M.S.; TOLON, Y.B. Uso de redes neurais artificiais na identificação de vocalização de suínos. EngenhariaAgrícola, Jaboticabal, v.28, n.2, p.204-216, 2008.

PAULY, C.; SPRING, P.; O’DOHERTY, J. V.; KRAGTEN, S. A.; BEE, G. Growth performance, carcass characteristics and meat qualityof group-penned surgically castrated, immunocastrated(Improvac $\left.{ }^{\circledR}\right)$ and entire male pigs and individually pennedentire male pigs. The International Journal of Animal Biosciences, Cambridge, v.3, n.7, p. 1057-1066, 2009.

RAULT, J-L; LAY JR., D. C.; MARCHANT-FORDE, J. N. Castration induced pain in pigs and other livestock. Applied Animal Behaviour Science, Amsterdam, v. 135, n. 3, p. 214-225, 2011.

RISI, N. Uso da vocalização como indicador patológico em leitões na fase de maternidade. 2010. 93 f. Dissertação (Mestrado) - Escola Superior de Agricultura "Luiz de Queiroz", Universidade de São Paulo, Piracicaba, 2010. 
SILVA, R.B.T.R.; NÄÄS, I.A.; MOURA, D.J.; SILVEIRA,N.A. Welfare norms for swine production under intensive rearing system.Brazilian Journal of Biosystems Engineering, Campinas, v.1, n.2, p. 137-145, 2007.

SMITH A.L.; STALDER K.J.; SERENIUS T.V.; BAAS T.J.; MABRY J. W.Effects of piglet birth weights at weaning and 42 days post weaning. Journal of Swine Health and Production, v. 15, n.4, p. 213-218, 2007.

TAYLOR, A.A.; WEARY, D.M. Vocal responses of piglets to castration: identifying procedural sources of pain. Applied Animal Behaviour Science, Amsterdam,v. 70, n. 1, p. 17-26, 2000.

TOLON, Y.B.; BARACHO, M.S.; NÄÄS,I.A.; ROJAS, M.;MOURA, D.J.Ambiências térmica, aérea e acústica para reprodutores suínos EngenhariaAgrícola, Jaboticabal, v.30, n.1, p.1-13, 2010. 